\title{
The Charterhouse of St. Lorenzo in Padula, an ideal mystical city of modern Campania
}

\author{
Francesca Castanò ${ }^{1}$ \\ ${ }^{1}$ University of Campania Luigi Vanvitelli \\ Email: francesca.castano@unicampania.it
}

\begin{abstract}
The essay explores the characteristics and themes of architecture related to Benedictine monastic life in the territories of Cilento and Vallo di Diano. The influences coming from the East and from beyond the Alps are adapted to local traditions without imitating early Christian models, as happens in other areas of Campania. The classical Greek elements acquire greater importance than the Roman universe. The previous buildings adapt to the western world and create heterogeneous hybrids that cannot be easily classified. The Carthusians introduce models that are consistent with a new formulation of the concept of the ideal city. The essay aims to analyze specifically the Certosa di Padula, in the heart of the Vallo di Diano, from the act of its foundation at the beginning of the fourteenth century until the impressive renovations during the eighteenth century. The monastic complex does not present itself as a safe haven from the perils of the world but becomes a spiritual place, the anticipation of Paradise on earth. On the one hand, respect for the strict rule of San Brunone and, on the other, constant interaction with the surrounding territory. The monastery constitutes a new type of polis. An ideality regulated by a rigid separation of the cloistered environments intended for the contemplation of the monks and those dedicated to community life. The boundary between the hermit's life in the upper domus and the cenobitic life in the lower domus is marked by the desertum, the large cultivated green space that gives access to the Civitas Dei, announced by the cartouche of the threshold "Felix coeli porta". The architectural structure of the Certosa di Padula, born on the basis of the models of Trisulti in Lazio and the motherhouse of Grenoble, reflects and embodies that ideal mystical city as declined by Thomas More who saw in monastic customs the foundation of Utopia.
\end{abstract}

(C) 2019 The Authors. Published by IEREK press. This is an open access article under the CC BY license (https://creativecommons.org/licenses/by/4.0/).

\section{Keywords}

Medieval Cilento; Carthusian architecture; ideal city; spiritual place

\section{Old monastic architecture in Cilento}

The Cilento and the Vallo di Diano, southern offshoots of Campania, appear to be lands of border and contrast lands, in the balance between classical permanence and Byzantine experimentation. The western art scene, marked by the spread of Benedictine monasticism, draws significant inspiration precisely from the formal universe of the Middle East, where the elements of tradition blend with imported cultures, generating an autochthonous language linked to the individual local realities. The results of cultures not coincident between them are translated in this area into a diversified artistic experience, at times eclectic, where the rituality of the cave architectures, the centric systems, is reinvented according to the needs of Western cult, instead linked to the simplifications of Desiderio abbot, the longitudinal development of early Christian heritage and the adherence to the stylistic elements of Roman world (Dall'eremo al cenobio, 1987, 425-575).The Early medieval syncretism characterized by the spread of Romanesque 
language far beyond the boundaries of regional localisms, shifts the terms of the analysis within Campania to a broader comparison (Venditti, 1967, 465-820). It is no coincidence, therefore, to frame the geographical divisions within wider territorial limits that, in the case under examination, range from Montecassino, to Cava ad Avellino up to the entire south of the peninsula and to Sicily, where the action of the Normans is emblematic in the artistic field (Bellafiore, 1990, 9-34, 71-79). Even in spatial terms, the guidelines to be defined appear weak, temporary and changeable. The period of spread of the post-Cluniac reform, from the year thousand up to the entire thirteenth century, coincides temporally with the extended chronological period to which variously refers the terminus a quo of the history of Italian art. Benedictine monasticism probably moves in the sign of linguistic research that intends to bend the foreign formal codes, coming from the East and from the regions beyond the Alps, to the local traditions (Romanini, 1974, 790-827).

\section{The Benedictine Latinization}

The return to an older order promoted first by Desiderio, then by Alfano, Pietro, Costabile, or by the promoters of the reformed rule, cancels and, blocks, at the same time, the current linguistic innovation, recovering the compositional messages of the first Christianity. It is not to be believed, however, that the roots of an Italian artistic identity can be found only in the simple repetition of early Christian models, informed by the lessons of late Roman times. The rational approach of the Benedictine church programs, in fact, does not exclude, rather integrates and makes its own, the experiences of local cultures and the inevitable contributions of Islamic civilizations, from Fatimid of North Africa to Iranian. Especially in the areas located in the extreme south of the Campania region, where Calabrian and, in particular, Sicilian influences, directly connected to the Islamic experiments, favour the diffusion of a language linked to Greek classicism, rather than Roman. Just think of the frequent contacts between the abbey of Cava dei Tirreni and the cathedral of Monreale, at the time of Pietro da Salerno (Bottari, 1955, 7-28).

In the history of these places the Greek tradition, as a dominant element of classicism, assumes a strong incidence. The Latinisation promoted by the Benedictines meets in Campania, in the regions of Cilento and Vallo, the greatest resistance. The Basilian rite, positively received by the local populations, for the attractive abilities exerted by the Christian cult, had involved a greater control of the countryside both in productive and economic terms, holding back the devastating Saracen incursions. The very impracticability of the narrow strip of land between the Alburni, the Picentini mountains and the sea, crossed only by the 'salt road', which led from Velia to the Tanagro Valley and the ancient road from Capua to Reggio through the valley of Teggiano, had allowed over time the extensive penetration from the south of the Italo-Greek monks, favored by the Byzantine occupation. The characteristics of Greekness in the territories bordering Calabria assume, therefore, an absolute hegemony with respect to the permanence of Roman tradition, where the specificity of the archaeological emergencies of Poseidonia and Velia, Cilento sites of ancient Magna Graecia, claim to belong to a historical culture of particularly Hellenistic origin.

This return to the classic does not translate here into an integral work of the rebuilding of the reformed Benedictines, but rather into a heterogeneous hybridization of different characters difficult to identify (Bettini, 1966). Byzantine remains can be found in the single-apsidal single-room churches, such as in the cases of S. Maria a Corte in Olevano and S. Mattia de Tusciano in Battipaglia, both currently in a state of ruin, which can be traced back to the numerous Calabrian examples of pre-Norman foundation. The use of the longitudinal layout, on the other hand, highlights the more eloquent use of the early Christian model, among the founding themes of the mid-Byzantine renovatio In the Cluniac inspired Cassinese programs, the use of spolia, or rather the reuse of ancient elements, is no longer considered constructively convenient. In the process of Latinisation of the territories of the lower Campania region, an independent analysis is required for the Rupestrian monasteries, particularly widespread in these geographical areas, which have passed from the Basilian or pagan rite to the Benedictine one without obvious traces. Among the most emblematic cases in which the mixture of the two languages, eastern and western, still cannot be considered implemented, are the caves of Olevano del Tusciano and Sant'Angelo a Fasanella, both dedicated to the cult of St. Michael the Archangel (Kalby, 1963-64, 205-227). The cases of the rupestrian monasteries highlight how sacred places, now transferred among the assets of the abbey of Cava, do not represent the signs of this nodal passage, leaving intact the formal declinations and the compositional solutions of the previous rite. An answer could derive 
from the more general consideration, debated by historiography, according to which it does not seem exact to speak of a real Benedictine architecture «nel senso di direttive unitarie da tradurre in specifici schemi architettonici e applicare nei cantieri dell'ordine», a condition very evident in the region of Cilento (Lenza, 2002, 45-237). The intention of monastic life, not contemplating in the rules any constructive prescriptions, is substantiated in changing and non-standard models, without those characteristic motifs recurring in the vast Benedictine production. In the case of the cave of Sant'Angelo a Fasanella, for example, the lions at the base of the external portal, the sculptures inside the church and the wall decorations, recall the linguistic vocabulary of Romanesque architecture rather than decorative elements of the Desiderian repertory. This phenomenon should be framed in more general terms. The dispersion of Christian settlements in the countryside is a direct cause of the collapse of urban life. If in the middle of the Byzantine period the ruralization of society causes a dislocation in independent religious monads of the city community, with the consequent atomization of the various parts making up the conventual structure; in the Benedictine era the phenomenon takes the form of a wider territorial organization, which sees the monastic complex transformed into a productive structure and economic control (Tosco, 2003; Del costruire, 2003). The transit of the reformed monks to the south of Campania leaves no tangible traces of a Desiderian phase, if not linked to the autonomous diffusion of the Romanesque language of Salerno declination; no sign of a decisive early Christian recovery if not contaminated by the experiences of Byzantine brand; no pre-eminence of elements of Roman tradition if not borrowed from the consumption of Hellenistic language (Bracco, 1982). The cenobitic character of Benedictine monasteries, while creating the conditions for a model of community life to be exported even outside the convent fences, does not seem to be fully measured by the ability to model the space of contemplation according to a common code of reference, inspired by the silentium and the escape from the world.

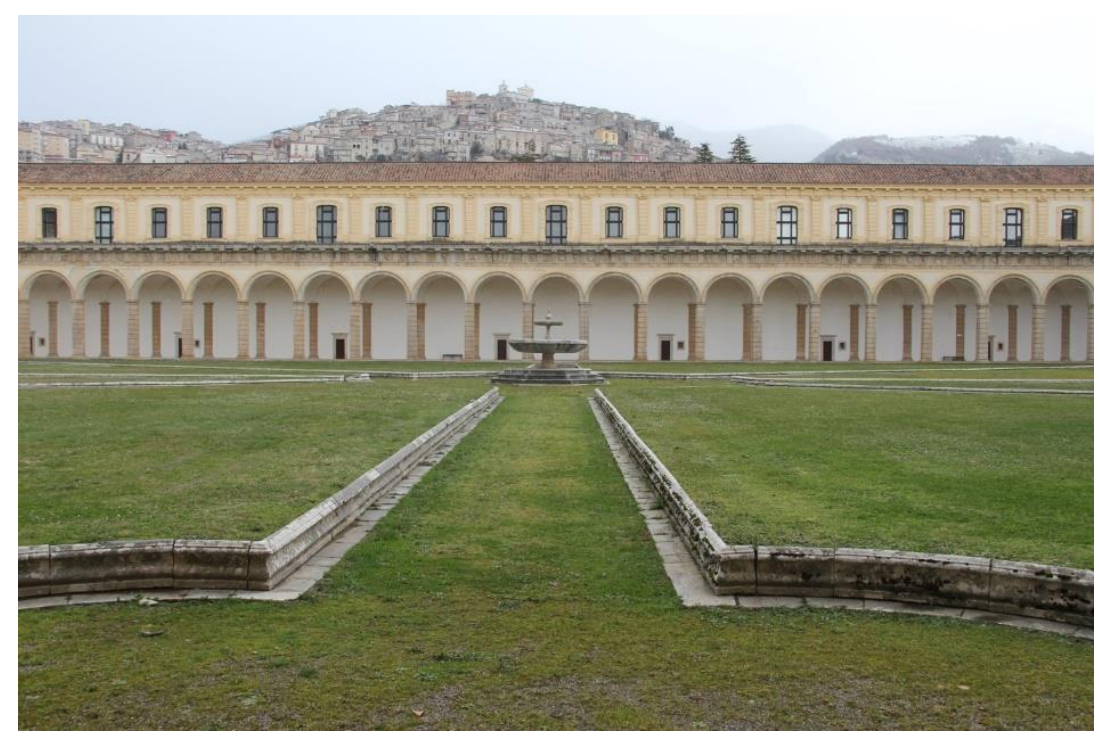

Figure 1. The main cloister of the Certosa

\section{The Carthusians of Padula}

A particular integration with the territorial context emerges from the analysis of the Carthusian complex of San Lorenzo a Padula, of the fourteenth century. In the architectural production of the order founded by San Bruno in 1084 , only some of the characteristics of uniformity and diffusion took from the dominant model of departure can be found (Certosini, 1993, 625-635; Certose e Certosini, 1990). The main cloister, around which gravitate the cells of the monks and the environments of community life to constitute the domus superior and the domus inferior with the complex of structures of service to use, instead, of the converged. These are the only two spatial elements founded in the organization of the newly founded Carthusian monasteries. The high house inaccessible to strangers, is the real Civitas Dei, marked by the scroll on the threshold of the large facade inside the Charterhouse of Padula "Felix coeli porta", which once crossed reveals the immense and regulated cloistered spaces, the precise and clear forms, the oblique lines of the paths, the majesty of the geometric design of the whole, as ideal conditions for utopian instances (De Cunzo, De Martini, 1985). The separation between the two types of life, eremitic, dedicated to fathers, cenobitic, for the converts, turns out to be the only constant to which refer also the development in the church plant. With a 
single hall, covered with cross vaults set on ogival arches, the church of Padula has, in fact, two distinct choirs, one on the side of the presbytery, designed for the former with access from the 'high house', and the other, for the brothers, near the entrance from the 'low house'. It is precisely in the sign of this absolute division between ascetic, solitary and secular life, that the process of settlement in the territory of the Carthusian rule can be inscribed. The respect of the rule of San Brunone, on one hand and the constant interaction with the surrounding territory on the other hand, make it an almost unique example of an "ideal city", regulated and modeled within its enclosure as a perfect spiritual, branched and polycentric polis in sub-regional estates (De Cunzo, 1990). On a large scale, this dichotomy translates into a declared exclusion from the context, into desertification of the surrounding area, such as to guarantee the hermitage of the entire Carthusian complex (Alliegro, 1994). The sense of belonging to the place is completely denied by the desire for isolation, which expands far beyond the confines of the desertum, the area that cannot be built on in the immediate circumstances of the Carthusian monastery. It presents itself as «una piccola città-stato, con dei cittadini che vi risiedono volontariamente, partecipano del suo governo e sottostanno alle sue regole, visibili nella sua stessa struttura architettonica» (Aversano, De Vita, Siniscalchi, 2009, 678). For this reason, the city-certosa must be autonomous and isolated, enclosed and compact and at the same time accessible and usable, manifest and inclusive for those who respect its moral and divine laws. The system of hereditary donations to the Fathers of San Lorenzo started by the Sanseverino family, in particular, together with the major tenants of the area, proved to be the necessary tool for the Carthusians to dispose of the annexed territories in absolute autonomy, even with respect to the neighboring dioceses. From the end of the fourteenth century until at least the beginning of the sixteenth century, the monastery of Padula redefined its territorial boundaries for the annexation of vast areas between Diano and Buonabitacolo. These were essentially hamlets and wooded areas, such as the Difesa Rofriddo, Serra Rotonda and Valle Vignola, which, having passed under Carthusian control, became the exclusive property of the monastery, without the local citizens being allowed to «far pascere i loro animali». The intention of the Carthusian fathers was essentially to manage the productivity of the new territories without intermediation, through the detached structures of the granges. Introduced in Italy after the Cluniac reform, the rural cell, if for the Cistercians and especially for the Virginians from agricultural settlement, then assumes over time the urban characteristics, in the case of the Carthusians remains instead an isolated and autonomous territorial unit, which exports outside the abbey enclosure, the model of the hermit cell of the domus superior (Manselli, Pasztor, 1987, 76).

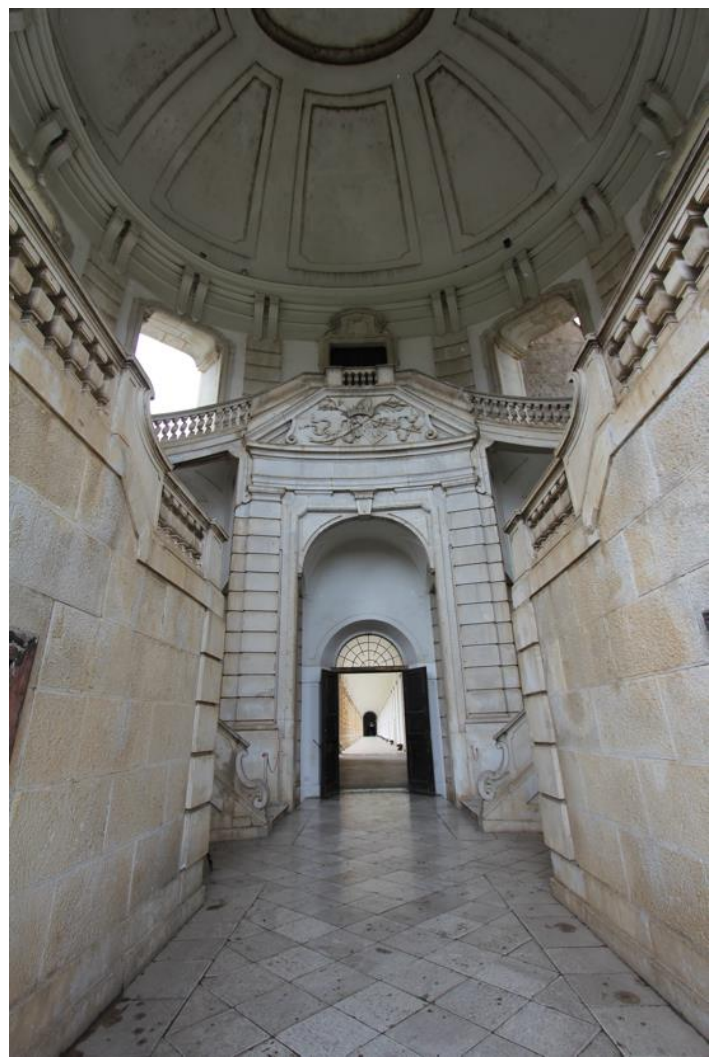

Figure 1. The monumental staircase (Gaetano Barba, 18th Century) 


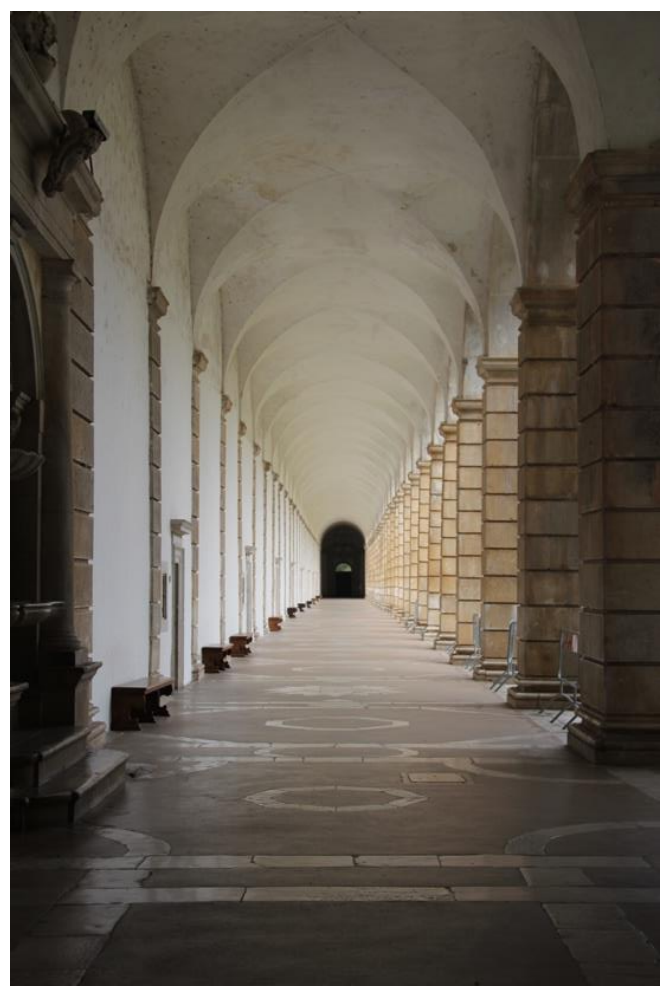

Figure 2. The wing of the main cloister

This is the case, for example, of the Grancia di Cadossa, between Casalbuono and Montesano, which was included among the properties of the Certosa di San Lorenzo. Enclosed within a large enclosure, the complex of Santa Maria di Cadossa, despite the many renovations over time, still retains its character of isolation from the surrounding area. The monks' service structures, together with the small church with access from the internal court-yard, and the detached parts used for production activities, restore within the turreted rectangular perimeter, the sense of closure towards the outside, derived from the motherhouse. The ascetic ideal and the cenobitic life merge, in the case of the Carthusian crab, into a complete, independent, spatial unicum, indifferent to the context.

This would derive from the hermit's approach of the Carthusians, a movement originating from the need for a more intense and perfect Christian life, matured in a social and cultural environment profoundly different from the Benedictine one (Aversano, De Vita, Siniscalchi, 2009, 675-702). If the reformed order under the banner of the ora et labora is, in fact, rooted in the countries beyond the Alps, it is no coincidence that in southern Italy knows the greatest diffusion. The Byzantine echoes of a hermit's character are the essential conditions for a return to full asceticism advocated by St. Bruno. In these geographical areas at the border of Greece, the Carthusian rule, better than elsewhere, claims its religious affiliation to the Islamic heremitage. The cultural continuity with respect to an ancient tradition, not exclusively of Latin brand, would explain, therefore, the concentration of Carthusian settlements in lower Campania and Calabria, where the Byzantine permanence was still persistent. It is precisely the predominantly hermit's will of the new order that causes, however, on a territorial scale, the absolute isolation of these geographical areas, compared to the rest of the peninsula. The rapid expansion of the rule stopped, in fact, from the fourteenth century, the urban growth of all centers near the Charterhouse of Padula. The policy of annexation should obviously be read as a natural extension of that philosophy of the desertum, applicable by the Carthusian monks indiscriminately to the abbey complex, as to the territory of their own relevance. The result is complex geography, with a sort of mega-Carthusian village, compact and closed to the outside, forming on the border between Calabria and Campania.

\section{Conclusions}

The Carthusians introduce models that are consistent with a new formulation of the concept of the ideal city. The monastic complex does not present itself as a safe haven from the dangers of the world, but becomes a spiritual place «sign and anticipation of paradise» on earth (Leoncini, 1988). 
On the one hand, respect for the strict rule of San Brunone and, on the other, constant interaction with the surrounding territory. The monastery constitutes a new type of polis. A perfect polis that in its rational planimetric form and in the separation of functions expresses the religious and moral order. In the confusion of the outside world, it is an «island of serenity and order», as defined by Lewis Mumford (Mumford, 1967). An ideality regulated by a rigid separation of the cloistered environments intended for the contemplation of the monks and those dedicated to community life. The architectural structure of the Certosa di Padula, born on the basis of the models of Trisulti in Lazio and the motherhouse of Grenoble, reflects and embodies that ideal mystical city as declined by Thomas More who saw in monastic customs the foundation of Utopia (Dematteis, 1963, 395-421). He identifies in the chartusian rule and in the form of the Chartehouse the perfect city. Thomas More was a layman attracted by monastic life and for some time lived near the monastery participating daily in the spiritual life of the Carthusians, It was Moro himself in 1516 who first coined the term Utopia. What is Utopia? It's a land of perfect harmony, where justice prevails and where iniquities have been banned. This ideal city has a square perimeter and extends from the top of a hill to a river. There are stone arches and safe enclosures that separate it from the outside world. Within this joyful community private property does not exist, every citizen dedicates himself to agriculture and thinks about the common good. The appearance of the Utopias on the ideal city introduced by Renaissance philosophers coincides with the vision of a perfect community, as interpreted by the rule of San Bruno. The result is ideal cities that resemble monasteries, according to the idea of the Cluniac reform, in a sort of harmony between speculative and active life. The monastic paradigm is very important for understanding modern utopia. Through an organized control of space, the city-Chartehouse aims to control the chaos of a disorderly and iniquitous reality that during the seventeenth century would in any case profoundly transformed the church and Catholic culture. While the culture of utopias at the same time was only at the beginning.

\section{References}

Alliegro, G. (1941). La Reggia del silenzio. Roma: Unione Editrice Sindacale Italiana.

Aversano, V., De Vita M.R. \& Siniscalchi S. (Eds) (2009). La Certosa di Padula e il suo territorio: una "città ideale" riscoperta e in via di valorizzazione. In A. Pellicano (Ed.), Città e Sedi Umane Fondate tra Realtà e Utopia, Tomo II. (pp. 675-702). Locri: Franco Pancallo Editore.

Bellafiore, G. (1990). Architettura in Sicilia nelle età islamica e normanna (827-1194). Milano: Arnaldo Lombardi Editore.

Bettini, S. (1996). L'arte alla fine del mondo antico. Milano: Universale di Architettura Testo\&Immagine.

Bottari, S. (1955). I rapporti tra l'architettura siciliana e quella campana nel Medioevo. Palladio, V, 7-28.

Bracco, V. (1982). La descrizione seicentesca della “Valle di Diana”, di Paolo Eterni. Sant'Arpino: Editrice Ferraro.

Castelnuovo, E. \& Sergi G. (Eds) (2003). Del costruire. Tecniche, artisti, artigiani, committenti, vol. II. Torino: Giulio Einaudi Editore.

Certose e Certosini in Europa (1990). Atti del Convegno alla Certosa di San Lorenzo, (Padula 22-24 settembre 1988). Napoli, Sergio Civita Ed.

Certosini (1993). In Enciclopedia dell'arte medievale, (vol. IV, pp. 625-635). Roma: Marchesi.

Dall'eremo al cenobio. La civiltà monastica in Italia dalle origini all'età di Dante, (1987). Milano: Libri Scheiwiller.

De Cunzo, M., De Martini, V. (1985). La Certosa di Padula. Firenze: Centro Di.

De Cunzo, M. (1990). La Certosa di San Lorenzo, Cassa di Risp. Salernitana. Milano: F. Maria Ricci Ed.

Dematteis, G. (1963). L'organizzazione del territorio nelle utopie sociali di T. Moro, T. Campanella, F. Bacone. Rivista Geografica Italiana, LXX, 395-421.

Kalby, G. (1963-64). La cripta eremitica di Olevano del Tusciano (I). Napoli nobilissima, III, 205-227.

Lenza, C. (2002). Architettura medievale: etica, estetica e tecnica. In A. Gambardella (Ed.), Dal Pantheon a Brunelleschi. Napoli: Edizioni Scientifiche Italiane, pp. 45-237.

Leoncini, G. (1988). Il monastero certosino: attuazione di un ideale. In Certose e Certosini, (1990), pp. 47-58.

Manselli, R. \& Pasztor, E. (1987). Il monachesimo nel basso Medioevo. In Dall'Eremo, (1987), pp. 67-123.

Mumford, L. (1967). La città nella storia. Milano: Etas Kompass.

Romanini, A.M. (1974). Architettura monastica occidentale. In Dizionario degli Istituti di perfezione. Milano: Paoline.

Sacco, A. (2004). La Certosa di Padula, disegnata, descritta e narrata su documenti inediti con speciale riguardo alla topografia, alla storia e all'arte della contrada (rev. ed). Salerno: Laveglia.

Tosco, G. (2003). Il castello, la casa, la chiesa. Architettura e società nel medioevo. Torino: Giulio Einaudi.

Venditti, A. (1967). Architettura bizantina nell'Italia meridionale. Campania, Calabria, Lucania. Napoli: Edizioni Scientifiche Italiane. 